\title{
Low-energy Hydraulic Fracturing Wastewater Treatment via AC Powered Electrocoagulation with Biochar
}

\author{
Fernanda Leite Lobo, Heming Wang, Tyler Huggins, James Rosenblum, Karl G. Linden, \\ Zhiyong Jason Ren ${ }^{*}$ \\ Department of Civil, Environmental, and Architectural Engineering \\ University of Colorado Boulder, Boulder, Colorado 80309
}

Corresponding author Ren E-mail: zhiyong.ren@colorado.edu

Phone: (303) 492-4137; Fax: (303) 492-7317 


\begin{abstract}
Produced and flowback waters are the largest byproducts associated with unconventional oil and gas exploration and production. Sustainable and low cost technologies are needed to treat and reuse this wastewater to avoid the environmental problems associated with current management practices (i.e. deep well injection). This study presents a new process to integrate $\mathrm{AC}$-powered electrocoagulation (EC) with granular biochar to dramatically reduce energy use and electrode passivation while achieving high treatment efficiency. Results show achieving a 99\% turbidity and TSS removal for the AC-ECbiochar system only used $0.079 \mathrm{kWh} / \mathrm{m}^{3}$ or $0.15 \mathrm{kWh} / \mathrm{kg}$ TSS, which is $70 \%$ lower than traditional DC-EC systems and orders of magnitude lower than previous studies. The amount of biochar added positively correlates with energy saving, and further studies are needed to improve organic carbon and salt removal through system integration.
\end{abstract}

Keywords: Electrocoagulation, Biochar, Produced Water, low energy wastewater treatment, hydraulic fracturing. 


\section{Introduction}

Produced and flowback waters are the largest byproducts associated with oil and gas exploration and production. Approximately 21 billion barrels of produced water is generated each year from about 900,000 wells in the United States alone [1], and more than $90 \%$ of the water is currently deep-well injected. Technologies are being developed and implemented to treat and reuse this type of wastewater onsite, so the negative effects of seismic activity, traffic congestion, increased water demands, and potential contamination resulting from underground injection can be alleviated, and operational cost can be reduced. Electrocoagulation (EC) is among these technologies that are being used to remove suspended solids especially emulsified oil particles from water so it can be reused for re-fracking. Compared with traditional chemical coagulation, EC is more attractive due to the lack of chemical required, less sludge production, and simpler operation needs [2-5]. However, traditional EC process consumes 0.5 to $6.25 \mathrm{kWh} / \mathrm{m}^{3}$ of electricity depending on water conductivity and other factors, and the conversion from AC to DC at high current condition is expensive [6]. For example, a pilot study showed a $1 \mathrm{~m}^{3} / \mathrm{h}$ EC reactor required $2.25 \mathrm{kWh} / \mathrm{m}^{3}$ to reduce oil concentration from $478 \mathrm{mg} / \mathrm{L}$ to 20 $\mathrm{mg} / \mathrm{L}$ from produced water with conductivity of $1000 \mathrm{mS} / \mathrm{m}$ [7]. In addition, the current EC process suffers an electrode passivation problem, leading to short operation time and high cost [6]. Such challenges are especially difficult when EC is used in produced water treatment, because the availability of electricity is limited and system maintenance is expensive.

This study presents a new method of EC operation to significantly reduce energy consumption and electrode passivation by introducing alternating current (AC) and low- 
cost granular biochar. Recent studies compared the energy consumption between DC and AC powered EC for cadmium, copper, iron, fluoride and arsenate removal [8-12], and it was found that AC powered EC used 10-66\% less energy. Studies also found that AC delayed cathode passivation and anode deterioration [13]. The addition of adsorptive particles such as granular activated carbon (GAC) can scour the electrode surface to reduce electrode fouling, and the adsorptive nature will improve the removal of particulate and dissolved contaminants [14-16]. The downside of using GAC is the high material cost, considering the price of GAC ranges from 800-2500 US\$/ton. To maximize the energy saving while reducing cost, we integrated the AC-EC process with granular biochar as adsorptive material. The recently developed biochar is derived from local waste biomass from agricultural and forestry residues, and its pyrolysis manufacturing process is much easier than GAC, so the cost is nearly ten times lower than GAC, in the range of 51 to $381 \mathrm{US} \$$ /ton [17]. Biochar has been shown as an effective adsorption media for heavy metal and organic carbon removal $[18,19]$ but has not been widely used in produced water treatment. The system efficacy and energy consumption for treating produced water were compared in DC-EC and AC-EC systems, and the effects of granular biochar were characterized under different doses at $0 \mathrm{~g} / \mathrm{L}, 0.25$ $\mathrm{g} / \mathrm{L}$ and $0.5 \mathrm{~g} / \mathrm{L}$.

\section{Materials and Methods}

The produced water samples were collected from a hydraulic fracturing site located in the Denver-Julesburg basin. The characteristics of the water were: $\mathrm{pH}=7.6$, Turbidity $=400 \pm 44$ NTU, Total suspended solids $(\mathrm{TSS})=514 \pm 47 \mathrm{mg} / \mathrm{L} ; \mathrm{COD}=$ 
$3,631 \pm 69 \mathrm{mg} / \mathrm{L}$, Conductivity $=46.1 \mathrm{mS} / \mathrm{cm}$. The biochar was made using lodgepole pine wood that was thermally converted in a top-lit up-draft (TLUD) gasifier at a highest heat temperature of $1000{ }^{\circ} \mathrm{C}$ at a ramp rate of $17^{\circ} \mathrm{C} / \mathrm{min}$. Detailed biochar carbonization process was described in previous studies by Huggins, et al [17,20]. After carbonization the biochar material was crushed and sieved using a 12x40 sieve without any chemical modification, and the sample was washed with distilled water and dried in an oven for 2 hours at $100{ }^{\circ} \mathrm{C}$ before use. Based on Brunauer-Emmett-Teller (BET) tests, the biochar has a surface area of $428.6 \mathrm{~cm}^{2} / \mathrm{g}$, a total area of $0.52 \mathrm{~m}^{2}$, and an average pore diameter of $37.6 \dot{A}$. The cost of biochar was estimated approximately $0.000504 \mathrm{US} \$ / \mathrm{m}^{2}$ based on previous studies. An electron scanning microscope image of the biochar is presented in the supplementary material (Figure S1) [17].

The electrocoagulation system has a working volume of $200 \mathrm{~mL}$ and used two $28.16 \mathrm{~cm}^{2}$ aluminum electrodes that are $3 \mathrm{~mm}$ apart. The experiment was carried out in six different conditions: DC-EC with $0 \mathrm{~g} / \mathrm{L}$ biochar, DC-EC with $0.25 \mathrm{~g} / \mathrm{L}$ biochar, DCEC with $0.5 \mathrm{~g} / \mathrm{L}$ biochar, AC-EC with $0 \mathrm{~g} / \mathrm{L}$ biochar, AC-EC with $0.25 \mathrm{~g} / \mathrm{L}$ biochar, and AC-EC with $0.5 \mathrm{~g} / \mathrm{L}$ biochar, respectively. Biochar adsorption control without current was performed under $0.25 \mathrm{~g} / \mathrm{L}$ and $0.5 \mathrm{~g} / \mathrm{L}$ as well. The experiments were conducted under a fixed voltage of $1.2 \mathrm{~V}$ and variable currents using a 3644A DC power supply 018V/0-5A. The frequency used in AC-EC process was $3.33 \mathrm{mHz}$ with polarity changed every 5 minutes. The duration of the electrocoagulation operation varied from 30 to 50 minutes in order to achieve $99 \%$ turbidity removal, which was the target for produced water treatment. Water samples were settled for 60 minutes before analyzed for $\mathrm{pH}$, conductivity, turbidity, TSS and COD. The $\mathrm{pH}$ was measured using a $\mathrm{pH}$ meter (Thermo 
Scientific, Orion ${ }^{\mathrm{TM}}$ Star A216); conductivity was measured using a conductivity meter (Hach, HQ440d); turbidity was measured using a turbidimeter (Hach, 2100N); and TSS and COD were measured using a standard photometric and colorimetric method (Hach Company, CO), respectively. Each experiment was done in triplicate, and no statistical difference was found, so the results were averaged. The residual Alum concentration was calculated according to the Faraday's Law,

$$
m=\frac{I t M}{Z F}
$$

where $I$ is the electrical current (A), $t$ is the electrolysis time (s), $M$ is the molecular weight $(\mathrm{g} / \mathrm{mol}), Z$ is the number of electrons and $F$ is the faraday constant $(96485.3$ $\mathrm{C} / \mathrm{mol})$.

\section{Results and discussion}

\subsection{Produced water treatment performance under different conditions}

Figure 1 shows that the electrocoagulation system was able to remove around 99\% of the turbidity and TSS under all six operational conditions (DC or AC powered EC, with or without biochar). This is consistent with previous findings that EC can be an effective process for suspended solids removal. However, the addition of biochar significantly reduced the time it took to achieve a 99\% reduction in turbidity and TSS. That is the addition of $0.25 \mathrm{~g} / \mathrm{L}$ of biochar required only a 30 minute reaction time, while the same conditions without biochar took 50 minutes. For the EC systems with 0 gram biochar addition, the turbidity removal after 30 minutes was around $85 \%$ (data not shown). The $\mathrm{pH}$ and conductivity measured at the end of the experiments in each condition showed no significant changes compared to the feed water (Figure 2A, 2B). In 
the six operational conditions $\mathrm{pH}$ ranged from 6.5 (DC-EC with $0.25 \mathrm{~g} / \mathrm{L}$ biochar) to 7.5 (AC-EC with $0 \mathrm{~g} / \mathrm{L}$ biochar) and conductivity ranged from $42.8 \mathrm{mS} / \mathrm{cm}$ (DC-EC with 0 $\mathrm{g} / \mathrm{L}$ biochar) to $45.6 \mathrm{mS} / \mathrm{cm}$ (DC-EC with $0.25 \mathrm{~g} / \mathrm{L}$ biochar and AC-EC with $0 \mathrm{~g} / \mathrm{L}$ biochar). The average COD removal ranged from 5-14\% after 30 min (with biochar) and 50 min (without biochar), respectively.

Due to the long settling time before chemical measurements and limited water volume, we were not able to obtain time-course data similar to the AC/DC current profile (Figure 4), instead $99 \%$ removal of turbidity or TSS was set as a treatment goal to be consistent with general industry practice (personal communication). The 30 and 50 minutes reaction times for different conditions were examined during pre-testing to determine an approximate timeframe for $99 \%$ turbidity removal. This was done so energy calculations could be performed from a uniform baseline.

The removals of turbidity and TSS in biochar control without EC reactor are shown in Figure 3. After 30-miniute adsorption, 5\% of turbidity and 3\% of TSS were removed when $0.25 \mathrm{~g} / \mathrm{L}$ biochar was added. The removal increased to $15 \%$ for turbidity and $9 \%$ for TSS when biochar dosage increased to $0.5 \mathrm{~g} / \mathrm{L}$. These data show that a higher suspended solids removal was observed when combining EC and biochar in one system (>99\%) compared to the individual contribution by each process, suggesting a synergy existed in the EC-biochar operation. It is hypothesized that suspended solids coalesce with biochar into larger and lighter particles due to the low density and porous structure of biochar. With electrolytic microbubbles rising during the EC process, faster removal was accomplished for such particles as compared with regular flocs [7]. While this study 
focused on feasibility and energy savings, further studies are needed to understand these synergistic removal mechanisms.

\subsection{Energy benefits of the AC-EC-Biochar combination}

Figure 4 shows the current profiles under different conditions. During DC-EC operation, when no biochar was used, the average current was $62.1 \mathrm{~mA}$, giving an average current density of $22 \mathrm{~A} / \mathrm{m}^{2}$ (Figure 4A). Adding biochar significantly boosted the current during the first 4-5 minutes, but the current then dropped quickly and maintained at a comparable level to the DC-EC condition without biochar. The average current was $70.9 \mathrm{~mA}\left(25.2 \mathrm{~A} / \mathrm{m}^{2}\right)$ for $0.25 \mathrm{~g} / \mathrm{L}$ biochar, and the current was $60.9 \mathrm{~mA}\left(21.5 \mathrm{~A} / \mathrm{m}^{2}\right)$ for $0.5 \mathrm{~g} / \mathrm{L}$ biochar. The current fluctuation at the beginning is hypothesized to relate to the highly conductive nature of biochar in the solution, which was facilitated with the electron transfer. When the biochar settled with the flocs, the current dropped to nonbiochar levels, supporting the above hypothesis.

For the AC-EC system without biochar, the average positive current was $14.4 \mathrm{~mA}$ $\left(5.12 \mathrm{~A} / \mathrm{m}^{2}\right)$, while the average negative current was $26.9 \mathrm{~mA}\left(9.6 \mathrm{~A} / \mathrm{m}^{2}\right)$ (Figure 4B). The addition of biochar significantly shifted the current profile to the more positive region. When $0.25 \mathrm{~g} / \mathrm{L}$ biochar was added, the average positive current more than doubled to $31.9 \mathrm{~mA}\left(11.3 \mathrm{~A} / \mathrm{m}^{2}\right)$, while the negative current decreased to $19 \mathrm{~mA}$ (6.7 $\mathrm{A} / \mathrm{m}^{2}$ ). Higher shifts were observed when $0.5 \mathrm{~g} / \mathrm{L}$ was added, with positive current increased to $46 \mathrm{~mA}\left(16.3 \mathrm{~A} / \mathrm{m}^{2}\right)$ and negative current dropped to $6.55 \mathrm{~mA}\left(2.3 \mathrm{~A} / \mathrm{m}^{2}\right)$. The increase in the current is a result of the decrease of system resistance based on Ohm's law $\mathrm{R}=\mathrm{V} / \mathrm{I}$, because the voltage is at a fixed $1.2 \mathrm{~V}$ for all experiments. As shown in Figure 2, the conductivity of the solution remained stable, which indicates its inverse, 
or solution resistance, was stable. Also, since the distance between the two electrodes was kept the same, the change of electrode resistance due to scarification and passivation is believed to be the main reason for the current shift.

The energy consumption of all EC systems is shown in Figure 5. It is clear that overall the AC-powered EC consumed less energy than the DC-powered EC, and the amount of biochar added positively correlates with energy savings. The energy consumption of the DC-EC systems were of $0.263 \mathrm{kWh} / \mathrm{m}^{3}$ ( $0 \mathrm{~g} / \mathrm{L}$ biochar $), 0.213$ $\mathrm{kWh} / \mathrm{m}^{3}(0.25 \mathrm{~g} / \mathrm{L}$ biochar $)$, and $0.183 \mathrm{kWh} / \mathrm{m}^{3}(0.5 \mathrm{~g} / \mathrm{L})$, respectively. The energy consumption of the AC-EC systems were $0.103 \mathrm{kWh} / \mathrm{m}^{3}$ ( $0 \mathrm{~g} / \mathrm{L}$ biochar), $0.081 \mathrm{kWh} / \mathrm{m}^{3}$ (0.25 g/L biochar), and $0.079 \mathrm{kWh} / \mathrm{m}^{3}(0.5 \mathrm{~g} / \mathrm{L}$ biochar), respectively. When comparing with the DC-EC without biochar, the AC-EC reduced energy consumption by $61 \%$ yet achieved a similar turbidity and TSS removal, indicating switching DC to AC as EC's power source can lead to significant energy saving. The examination of electrode surface showed an impermeable oxide film formed on the DC-EC cathode, which requires higher current to maintain the reaction. The AC-EC system slowed such cathode passivation process and anode deterioration by inverting the polarity of the electrodes and creating a self-cleaning mechanism. Previous studies using scanning electron microscope (SEM) showed when AC-EC was used, the electrode surface presented a smooth microstructure of aluminum, suggesting the aluminum electrodes were dissolved uniformly during the electrolysis. When DC-EC was used the electrode surface presented disordered pores formed with dents. [8]. It is also known that AC electric fields can induce dipole-dipole interactions in a system with no spherical charged particles, therefore disrupting their stability [13]. 
A similar energy saving benefit was shown in biochar enhanced EC process for identical treatment goals. By adding $0.25 \mathrm{~g} / \mathrm{L}$ biochar, the energy consumption in the DCEC and AC-EC was reduced by $19 \%$, and $21 \%$, respectively. This saving further increased to $33 \%$ and $23 \%$, respectively, when $0.5 \mathrm{~g} / \mathrm{L}$ biochar was added. Overall, for achieving a similar 99\% turbidity and TSS removal, the combination of AC-EC and biochar saved up to $70 \%$ of energy (AC-EC plus $0.5 \mathrm{~g} / \mathrm{L}$ biochar vs. DC-EC without biochar). This translates to an energy consumption of $0.15 \mathrm{kWh} / \mathrm{kg}$ TSS, among the lowest energy expenditure in EC studies. Table 1 shows that previous studies reported 0.83-23.34 kWh of energy was used for every kg TSS removed in different EC systems, and the AC-EC-Biochar combination showed 35-99\% energy reduction compared with previous studies using EC systems for wastewater treatment.

\subsection{Future work is needed for system optimization and integration}

Despite the excellent energy savings and suspended solids removal capability, the EC systems used in this study showed limited removal for COD and TDS (Figure 2). While this is consistent with general findings that EC is not effective for COD or TDS removal, the combination of EC with other technologies has been reported for more advanced produced water treatment, including softening with EC [21], or EC combined with reverse osmosis [22]. Membrane based organic removal and desalination processes have been reported as EC post-treatment options, but they are energy intensive, consuming 10-600 kWh/m $\mathrm{m}^{3}$, depending on the technology used [23]. In this context, new technologies such as microbial capacitive deionization (MCD) could have a good synergistic relationship with an EC process [24]. This is the result of MCDs ability to 
remove COD and TDS, while generating electricity that can be used to power EC reactor, thus providing a pre-treatment step prior to MCD [25]. Though current MCDs have a low power output, recent developments in system scale-up and DC-AC converter shows the feasibility of system integration [26]. Other systems such as forward osmosis and membrane distillation may also be coupled with EC for the complete treatment and reuse of produced water, and more studies are needed to characterize and optimize these possible system integrations.

\section{Acknowledgements}

We thank the financial support from CAPES (Science without Borders) for FLL and National Science Foundation (IIP-1445084) for ZJR.

\section{References}

[1] C.E. Clark, J.A. Veil, Produced water volumes and management practices in the United Stated, 2009.

[2] S. Vasudevan, M. a. Oturan, Electrochemistry: as cause and cure in water pollution - an overview, Environ. Chem. Lett. 12 (2013) 97-108.

[3] S. Vasudevan, J. Lakshmi, G. Sozhan, Studies on the Al-Zn-In-alloy as anode material for the removal of chromium from drinking water in electrocoagulation process, Desalination. 275 (2011) 260-268.

[4] S. Vasudevan, J. Lakshmi, G. Sozhan, Electrocoagulation Studies on the Removal of Copper from Water Using Mild Steel Electrode, Water Environ. Res. 84 (2012) 209-219.

[5] S. Vasudevan, F. Epron, J. Lakshmi, S. Ravichandran, S. Mohan, G. Sozhan, Removal of NO3- from Drinking Water by Electrocoagulation - An Alternate Approach, CLEAN - Soil, Air, Water. 38 (2010) 225-229.

[6] V. Kuokkanen, T. Kuokkanen, J. Rämö, U. Lassi, Recent Applications of Electrocoagulation in Treatment of Water and Wastewater-A Review, Green Sustain. Chem. 03 (2013) 89-121.

[7] S. Rubach, I. Saur, Onshore testing of produced water by electroflocculation, Filtr. Sep. (1997). 
[8] S. Vasudevan, J. Lakshmi, G. Sozhan, Effects of alternating and direct current in electrocoagulation process on the removal of cadmium from water., J. Hazard. Mater. 192 (2011) 26-34.

[9] R. Kamaraj, P. Ganesan, J. Lakshmi, S. Vasudevan, Removal of copper from water by electrocoagulation process--effect of alternating current (AC) and direct current (DC)., Environ. Sci. Pollut. Res. Int. 20 (2013) 399-412.

[10] S. Vasudevan, J. Lakshmi, G. Sozhan, Studies on the removal of arsenate from water through electrocoagulation using direct and alternating current, Desalin. Water Treat. 48 (2012) 163-173.

[11] S. Vasudevan, Effects of alternating current (AC) and direct current (DC) in electrocoagulation process for the removal of iron from water, Can. J. Chem. Eng. 90 (2012) 1160-1169.

[12] S. Vasudevan, B.S. Kannan, J. Lakshmi, S. Mohanraj, G. Sozhan, Effects of alternating and direct current in electrocoagulation process on the removal of fluoride from water, J. Chem. Technol. Biotechnol. 86 (2011) 428-436.

[13] M.Y. a Mollah, R. Schennach, J.R. Parga, D.L. Cocke, Electrocoagulation (EC) science and applications, J. Hazard. Mater. 84 (2001) 29-41.

[14] M.S. Secula, B. Cagnon, T.F. de Oliveira, O. Chedeville, H. Fauduet, Removal of acid dye from aqueous solutions by electrocoagulation/GAC adsorption coupling: Kinetics and electrical operating costs, J. Taiwan Inst. Chem. Eng. 43 (2012) 767775.

[15] M. Secula, I. Cretescu, B. Cagnon, L. Manea, C. Stan, I. Breaban, Fractional Factorial Design Study on the Performance of GAC-Enhanced Electrocoagulation Process Involved in Color Removal from Dye Solutions, Materials (Basel). 6 (2013) 2723-2746.

[16] N. Vivek Narayanan, M. Ganesan, Use of adsorption using granular activated carbon (GAC) for the enhancement of removal of chromium from synthetic wastewater by electrocoagulation., J. Hazard. Mater. 161 (2009) 575-80.

[17] T. Huggins, H. Wang, J. Kearns, P. Jenkins, Z.J. Ren, Biochar as a sustainable electrode material for electricity production in microbial fuel cells., Bioresour. Technol. 157 (2014) 114-9.

[18] D. Kołodyńska, R. Wnętrzak, J.J. Leahy, M.H.B. Hayes, W. Kwapiński, Z. Hubicki, Kinetic and adsorptive characterization of biochar in metal ions removal, Chem. Eng. J. 197 (2012) 295-305.

[19] X. Tan, Y. Liu, G. Zeng, X. Wang, X. Hu, Y. Gu, et al., Application of biochar for the removal of pollutants from aqueous solutions., Chemosphere. 125 (2015) 7085.

[20] T.M. Huggins, J.J. Pietron, H. Wang, Z.J. Ren, J.C. Biffinger, Graphitic biochar as a cathode electrocatalyst support for microbial fuel cells., Bioresour. Technol. 195 (2015) 147-153.

[21] N. Esmaeilirad, K. Carlson, P. Omur Ozbek, Influence of softening sequencing on electrocoagulation treatment of produced water., J. Hazard. Mater. 283 (2015) $721-9$.

[22] S. Zhao, G. Huang, G. Cheng, Y. Wang, H. Fu, Hardness, COD and turbidity removals from produced water by electrocoagulation pretreatment prior to Reverse Osmosis membranes, Desalination. 344 (2014) 454-462. 
[23] G.P. Thiel, E.W. Tow, L.D. Banchik, H.W. Chung, J.H. Lienhard, Energy consumption in desalinating produced water from shale oil and gas extraction, Desalination. 366 (2015) 94-112.

[24] C. Forrestal, P. Xu, Z. Ren, Sustainable desalination using a microbial capacitive desalination cell, Energy Environ. Sci. 5 (2012) 7161.

[25] C. Forrestal, Z. Stoll, P. Xu, Z.J. Ren, Microbial capacitive desalination for integrated organic matter and salt removal and energy production from unconventional natural gas produced water, Environ. Sci. Water Res. Technol. 1 (2015) 47-55.

[26] F.L. Lobo, H. Wang, C. Forrestal, Z.J. Ren, AC power generation from microbial fuel cells, J. Power Sources. 297 (2015) 252-259.

[27] M.F. Ni'am, F. Othman, J. Sohaili, Z. Fauzia, Electrocoagulation technique in enhancing COD and suspended solids removal to improve wastewater quality., Water Sci. Technol. 56 (2007) 47-53.

[28] M. Kobya, E. Demirbas, a Dedeli, M.T. Sensoy, Treatment of rinse water from zinc phosphate coating by batch and continuous electrocoagulation processes., J. Hazard. Mater. 173 (2010) 326-34.

[29] L. Xu, B. Sheldon, D. Larick, R. Carawan, Recovery and utilization of useful byproducts from egg processing wastewater by electrocoagulation, Poult. Sci. 81 (2002) 785-792.

[30] N.P. Barkley, C.W. Farrell, T.W. Gardner-Clayson, Alternating Current Electrocoagulation for Superfund Site Remediation, Air Waste. 43 (1993) 784-789.

[31] M. Asselin, P. Drogui, S.K. Brar, H. Benmoussa, J.-F. Blais, Organics removal in oily bilgewater by electrocoagulation process., J. Hazard. Mater. 151 (2008) 44655.

[32] D. Valero, J.M. Ortiz, V. García, E. Expósito, V. Montiel, A. Aldaz, Electrocoagulation of wastewater from almond industry., Chemosphere. 84 (2011) $1290-5$.

[33] S. Kongjao, S. Damronglerd, M. Hunsom, Simultaneous removal of organic and inorganic pollutants in tannery wastewater using electrocoagulation technique, Korean J. Chem. Eng. 25 (2008) 703-709. 
Table 1. Energy requirement for suspended solids (SS) removal

$\begin{array}{ccc}\text { Reference } & \mathrm{kWh} / \mathrm{kg} \mathrm{SS} & \text { Details } \\ {[27]} & 23.34 & \text { DC EC, artificial wastewater } \\ {[28]} & 20.62 & \text { DC EC, Automotive wastewater } \\ {[29]} & 18.04 & \text { DC EC, egg processing wastewater } \\ {[30]} & 4.60 & \text { AC EC, superfund site remediation } \\ {[31]} & 3.91 & \text { DC EC, oily bilge water } \\ {[32]} & 0.83 & \text { DC EC, almond industry wastewater } \\ {[33]} & 0.23 & \text { DC EC, tannery wastewater } \\ \text { Our study } & 0.15 & \text { AC EC+biochar, produced water }\end{array}$




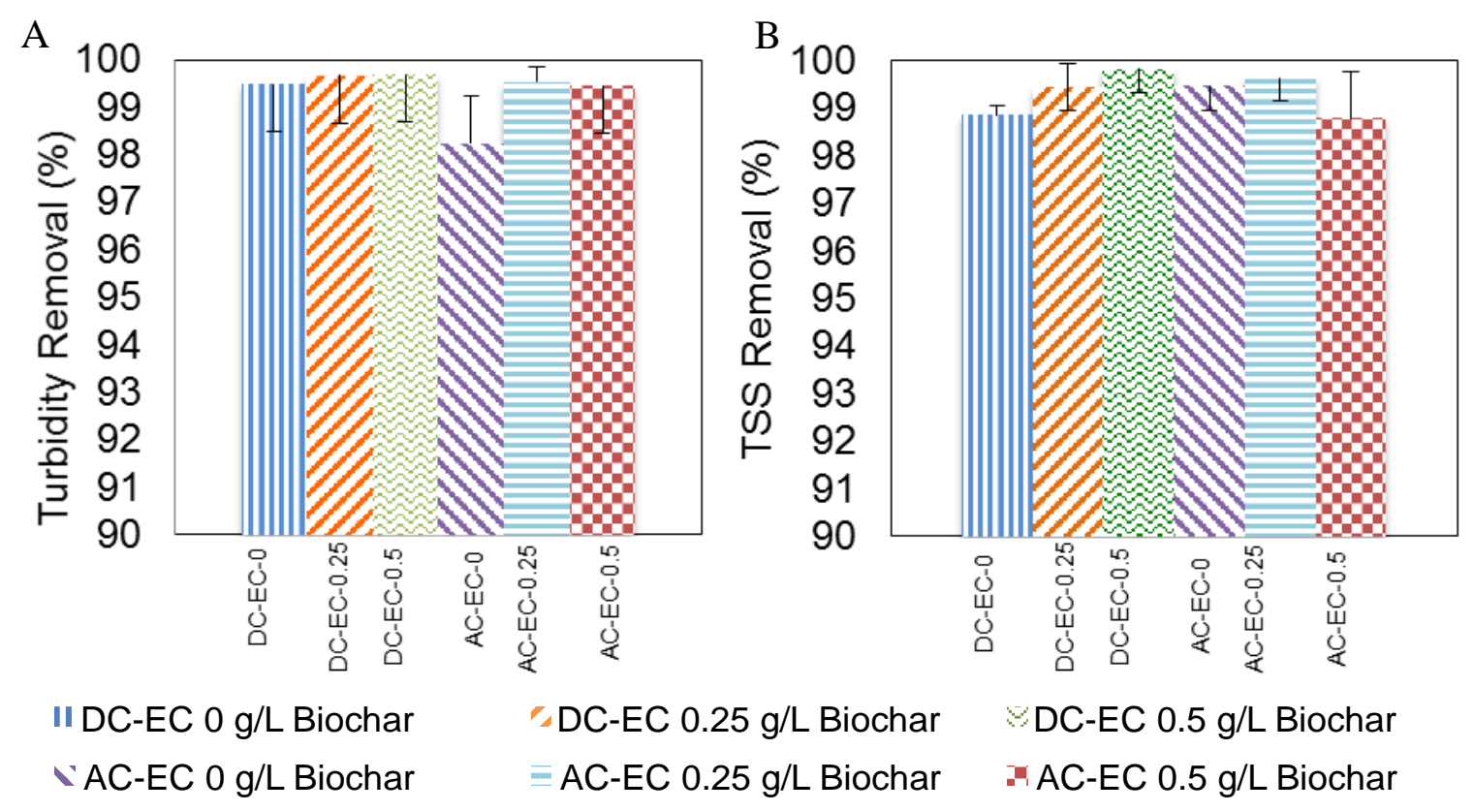

Figure 1. Turbidity (A) and TSS (B) removal by the 6 different operational conditions after 30 minutes (with biochar addition) or 50 minutes (without biochar addition). Legends showing process combination matrix, e.g. DC-EC-0 g/L Biochar means DC-powered EC process with $0 \mathrm{~g} / \mathrm{L}$ biochar addition. 

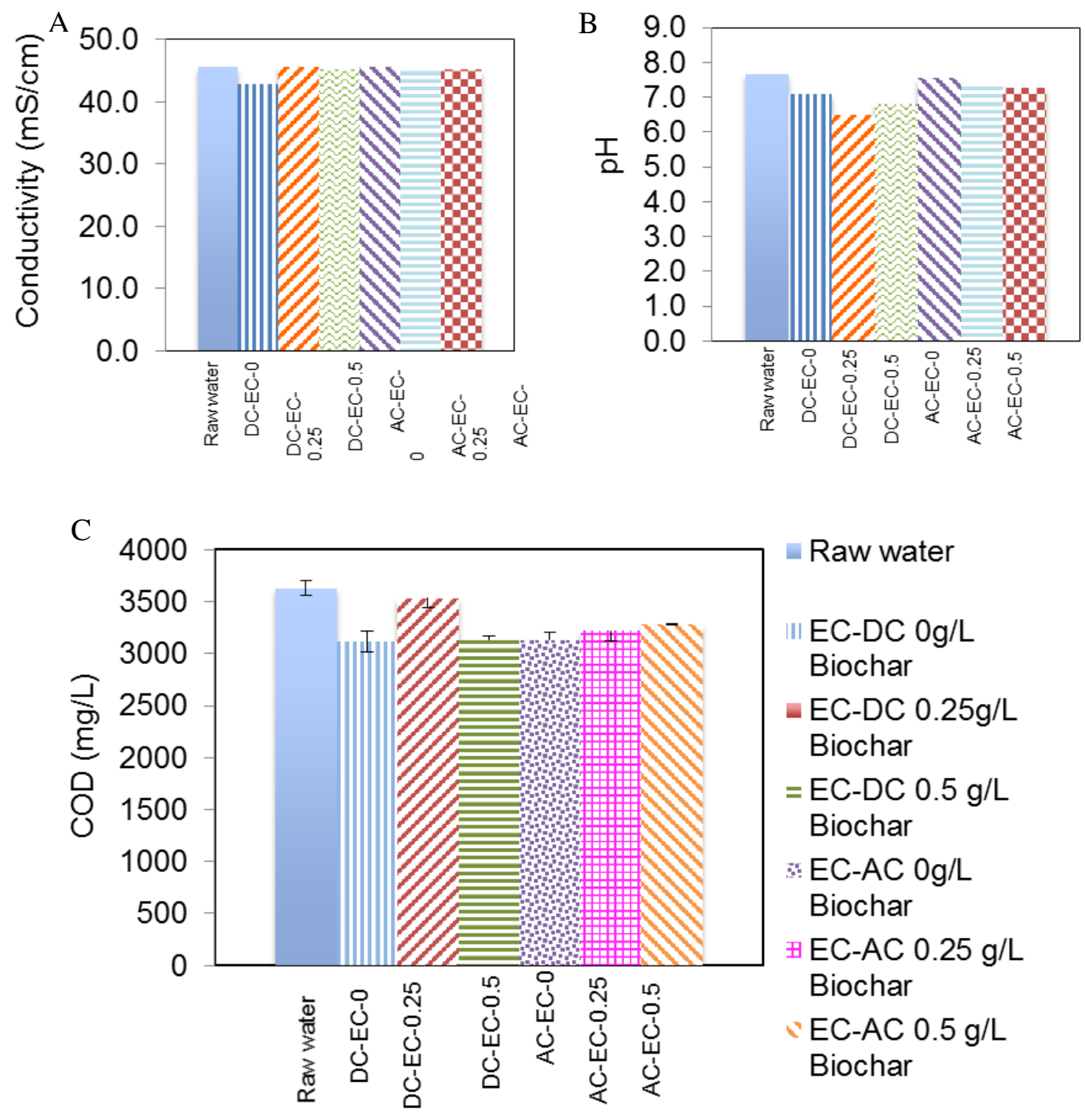

Figure 2. Change of solution conductivity (A) and $\mathrm{pH}(\mathrm{B})$, as well as COD removal (C) after 30 minutes (with biochar addition) or 50 minutes (without biochar addition). Legends showing process combination matrix, e.g. DC-EC-0 g/L Biochar means DC-powered EC process with $0 \mathrm{~g} / \mathrm{L}$ biochar addition. 

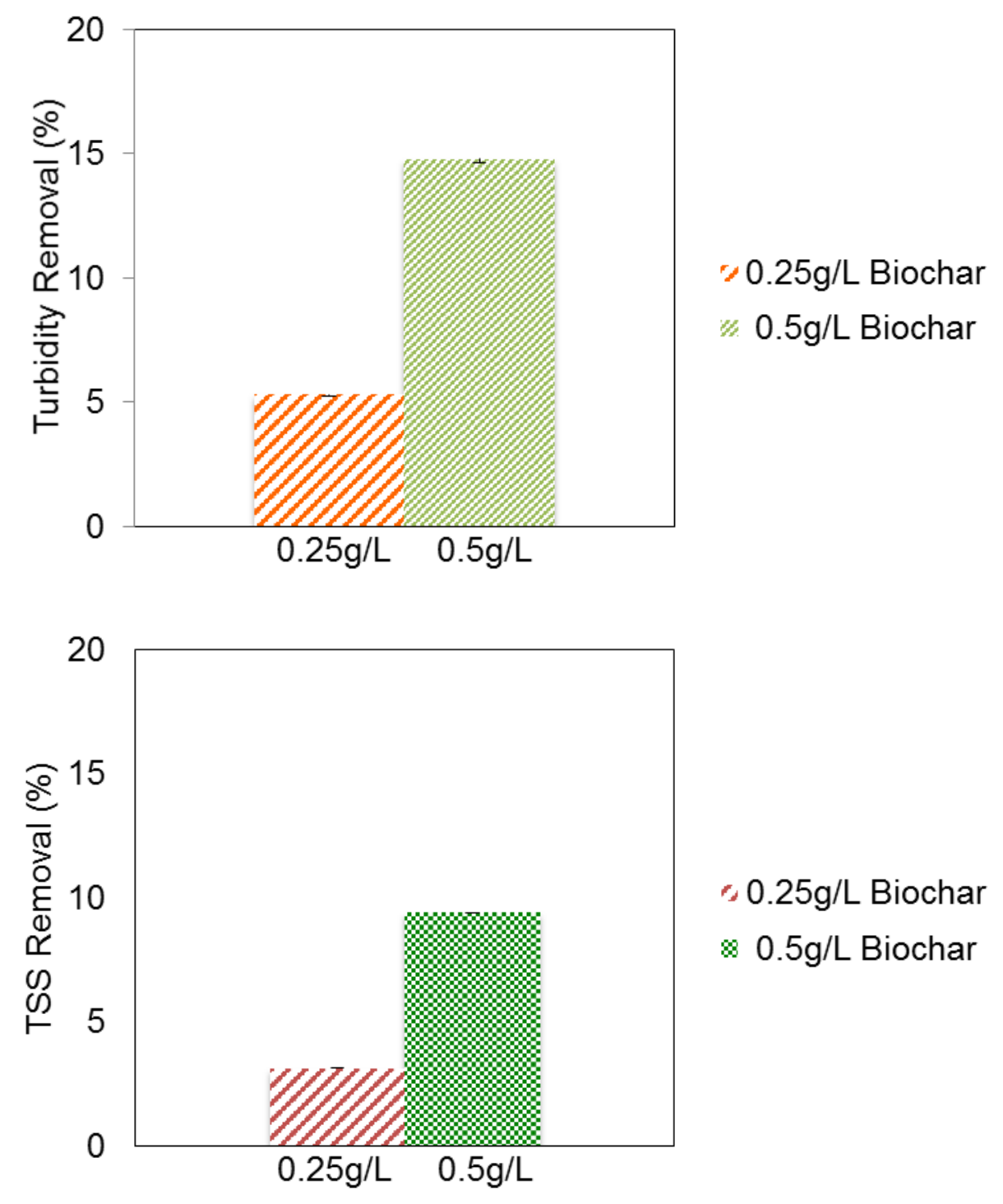

Figure 3. Turbidity and TSS removal after $\mathbf{3 0}$ minutes in biochar-only reactors with a dose of $0.25 \mathrm{~g} / \mathrm{L}$ or $0.5 \mathrm{~g} / \mathrm{L}$ biochar. 

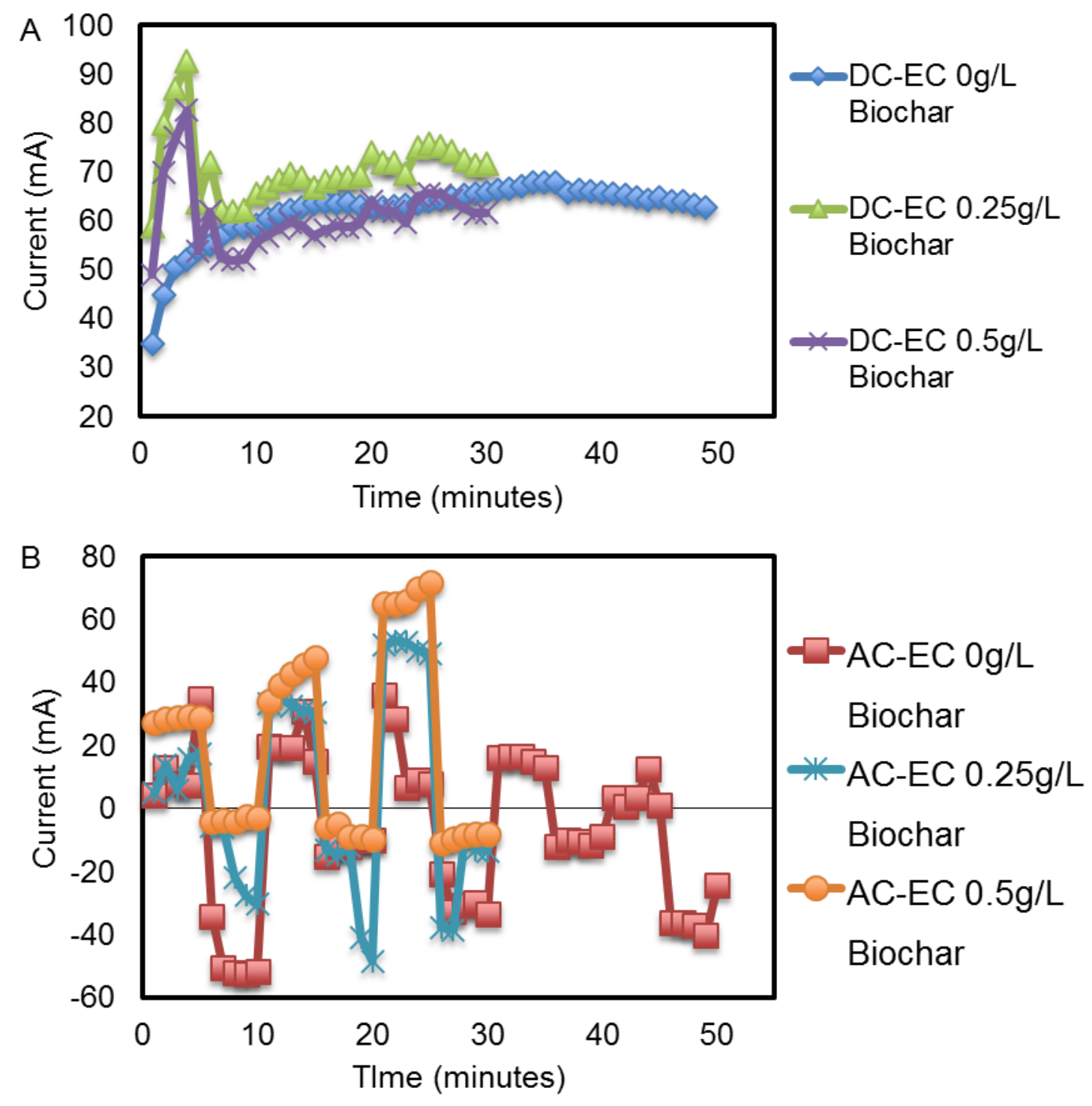

Figure 4. Time-course current profile in DC-EC reactors (A) and AC-EC reactors (B) with different doses of biochar addition. 


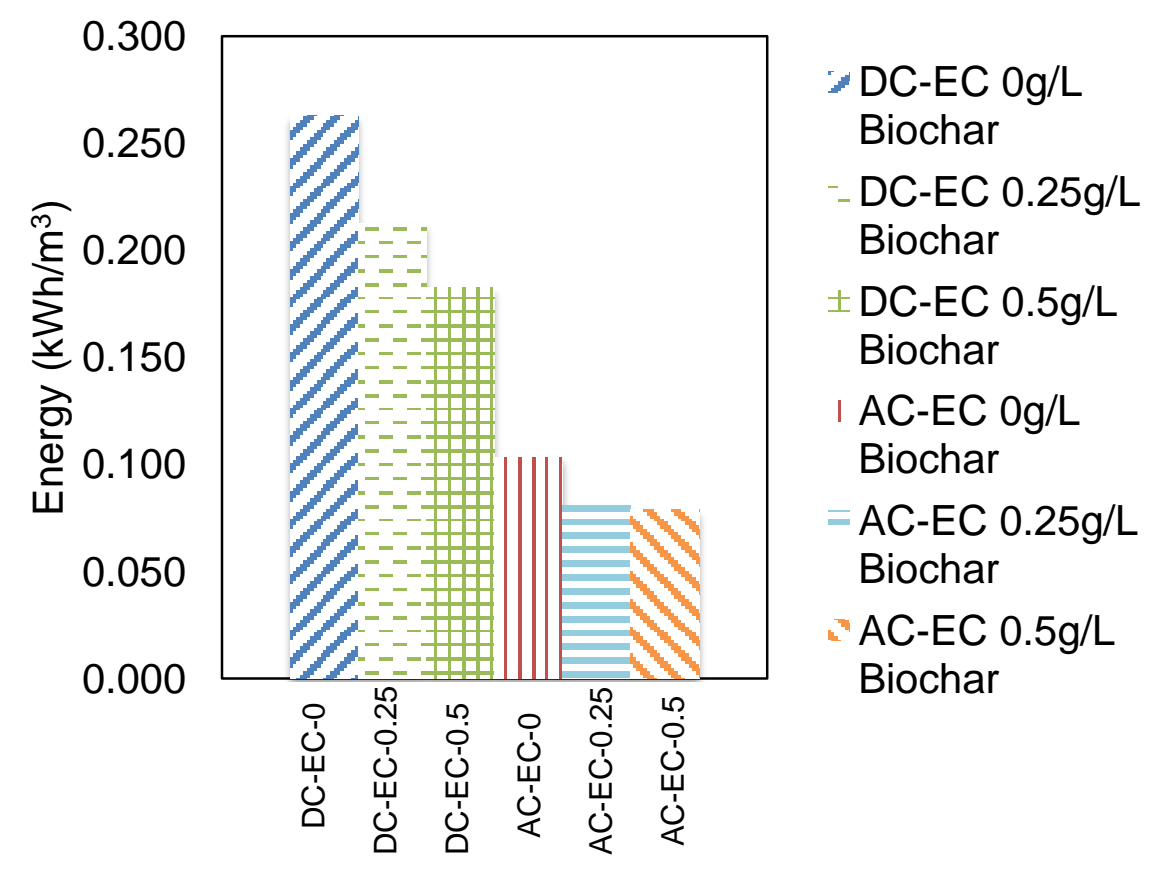

Figure 5. Energy consumption comparison under different conditions. 